\title{
A Single Exposure to Amphetamine Is Sufficient to Induce Long- Term Behavioral, Neuroendocrine, and Neurochemical Sensitization in Rats
}

\author{
Louk J. M. J. Vanderschuren, E. Donné Schmidt, Taco J. De Vries, Caroline A. P. Van Moorsel, \\ Fred J.H. Tilders, and Anton N. M. Schoffelmeer \\ Research Institute Neurosciences Vrije Universiteit, Department of Pharmacology, Medical Faculty, Free University, 1081 \\ BT Amsterdam, The Netherlands
}

Repeated treatment with psychostimulant drugs causes longlasting behavioral sensitization and associated neuroadaptations. Although sensitization induced by a single psychostimulant exposure has also been reported, information on the behavioral and neurochemical consequences of a single psychostimulant exposure is sparse. Therefore, to evaluate whether behavioral sensitization evoked by single and repeated psychostimulant pretreatment regimens represent the same neurobiological phenomenon, the time-dependent expression of behavioral, neurochemical, and neuroendocrine sensitization after a single exposure to amphetamine was investigated in rats. A single exposure to amphetamine (5 mg/kg, i.p.) caused context-independent sensitization of the locomotor effects of amphetamine, which intensified over time. Thus, sensitization to amphetamine was marginal at $3 \mathrm{~d}$ after treatment and more evident after 1 week, whereas 3 weeks after treatment, profound sensitization, as well as cross-sensitization, to cocaine was observed. Amphetamine pretreatment caused an increase in the electrically evoked release of $\left[{ }^{3} \mathrm{H}\right]$ dopamine from nucleus accumbens, caudate putamen, and medial prefrontal cortex slices and of $\left[{ }^{14} \mathrm{C}\right]$ acetylcholine from accumbens and caudate slices. The hyperreactivity of dopaminergic nerve terminals appeared to parallel the development of locomotor sensitization, i.e., whereas hyperreactivity of accumbens dopaminergic terminals increased between $3 \mathrm{~d}$ and 3 weeks after treatment, the hyperreactivity of medial prefrontal dopaminergic terminals decreased. Pre-exposure to amphetamine also sensitized the hypothalamus-pituitary-adrenal axis response to amphetamine at 1 and 3 weeks, but not at $3 \mathrm{~d}$ after treatment. Because these data closely resemble those reported previously for repeated amphetamine pretreatment, it is concluded that a single exposure to amphetamine is sufficient to induce long-term behavioral, neurochemical, and neuroendocrine sensitization in rats.

Key words: amphetamine; locomotor sensitization; dopamine release; acetylcholine release; nucleus accumbens; hypothalamus-pituitary-adrenal axis; caudate putamen; medial prefrontal cortex
Repeated exposure to drugs of abuse results in a progressive and enduring enhancement of their psychomotor and positive reinforcing effects. This phenomenon, termed behavioral sensitization (Stewart and Badiani, 1993), is thought to underlie certain aspects of drug addiction and drug-induced psychosis (Robinson and Becker, 1986; Robinson and Berridge, 1993; De Vries et al., 1998). The expression of behavioral sensitization relies on timedependent neuroplastic changes in the brain circuitry involved in motivational behavior. Of the numerous neuroadaptive phenomena involved, long-lasting hyperreactivity of the mesolimbic dopaminergic pathway has received most attention (for review, see Pierce and Kalivas, 1997).

The extent to which sensitization is induced by drug preexposure is highly dependent on the nature of the pretreatment regimen. Thus, repeated intermittent treatment with moderate doses of drugs is far more effective in inducing sensitization than chronic exposure to high or escalating drug doses (Post, 1980;

Received June 23, 1999; revised Aug. 11, 1999; accepted Aug. 12, 1999.

This work was supported by Netherlands Organization for Scientific Research (NWO) Grants 903-42-007 and 900-43-128.

Correspondence should be addressed to Dr. Louk J. M. J. Vanderschuren, Research Institute Neurosciences Vrije Universiteit, Department of Pharmacology, Medical Faculty, Free University, Van der Boechorststraat 7, 1081 BT Amsterdam, The Netherlands.

Copyright (C) 1999 Society for Neuroscience $\quad 0270-6474 / 99 / 199579-08 \$ 05.00 / 0$
Robinson and Becker, 1986; Stewart and Badiani, 1993; Vanderschuren et al., 1997). Interestingly, next to repeated intermittent and chronic administration schedules, which both use multiple drug exposures, even a single exposure to amphetamine or cocaine has been found to induce behavioral and neurochemical sensitization (Robinson et al., 1982; Robinson, 1984; Peris and Zahniser, 1987; Kalivas and Alesdatter, 1993). However, it is not clear whether sensitization induced by single and repeated psychostimulant exposure represents the same neurobiological phenomenon. For example, whereas there is a wealth of data on the neuroadaptive consequences of repeated psychostimulant treatment (for review, see White et al., 1995; Pierce and Kalivas, 1997; Wolf, 1998), information on the neuroadaptive effects of a single psychostimulant exposure is sparse (Robinson et al., 1982; Peris and Zahniser, 1987). Furthermore, repeated psychostimulant treatment can induce behavioral sensitization in both a contextdependent and a context-independent manner (Stewart and Druhan, 1993; Anagnostaras and Robinson, 1996; Robinson et al., 1998; Vanderschuren et al., 1999a). However, sensitization after a single drug pretreatment has only been investigated in a contextdependent manner, meaning that tests for sensitization were performed in the same environment in which pretreatment took place, allowing for association of environmental cues with drug effects. In view of the differences between context-dependent and context-independent behavioral sensitization, both behaviorally 
(Anagnostaras and Robinson, 1996; Robinson et al., 1998) and neurobiologically (Hoffman and Wise, 1992; Li et al., 1997; Mead and Stephens, 1998), it is of interest to investigate whether context-independent sensitization also occurs after a single psychostimulant exposure.

For these reasons, we evaluated the time-dependent behavioral, neurochemical, and neuroendocrine effects of a single exposure to amphetamine $(5 \mathrm{mg} / \mathrm{kg}$, IP) and compared them with the effects observed previously after repeated amphetamine treatment. Thus, the time course of amphetamine-induced contextindependent sensitization to the locomotor effects of amphetamine, as well as long-term cross-sensitization to cocaine and direct dopamine receptor agonists, was investigated. In addition, at various post-treatment intervals, we investigated the effect of amphetamine pre-exposure on the electrically evoked release of $\left[{ }^{3} \mathrm{H}\right]$ dopamine and $\left[{ }^{14} \mathrm{C}\right]$ acetylcholine from slices of nucleus accumbens, caudate putamen, and medial prefrontal cortex and on the secretion of ACTH and corticosterone elicited by a challenge with amphetamine.

\section{MATERIALS AND METHODS}

Animals and amphetamine pretreatment. All experiments were approved by the Animal Care Committee of the Free University of Amsterdam. Male Wistar rats (Harlan CPB, Zeist, The Netherlands), weighing 180$200 \mathrm{gm}$ at the time of amphetamine or saline pretreatment, were housed two per cage in Macrolon cages under controlled conditions (lights on from 7:00 A.M. to 7:00 P.M.). Animals were allowed to accustom to the housing conditions for at least 1 week before use. Food and water were available ad libitum. Animals were briefly handled on the $2 \mathrm{~d}$ preceding pretreatment and on the $2 \mathrm{~d}$ preceding subsequent drug challenges. Pretreatment consisted of a single injection with amphetamine $(5 \mathrm{mg} / \mathrm{kg}$, i.p.) or saline $(1 \mathrm{ml} / \mathrm{kg}$, i.p.), administered in the home cage. Amphetamine was dissolved in sterile saline.

Determination of locomotor activity. Horizontal motor activity was measured in perspex cages $(40 \times 40 \times 35 \mathrm{~cm})$ using a video tracking system (EthoVision; Noldus Information Technology B.V., Wageningen, The Netherlands), which determined the position of the animal five times per second. Experiments were started at approximately 9:30 A.M. White-noise was used to minimize the influence of surrounding sounds. Locomotor challenge tests were conducted as follows. Animals were allowed to habituate to the test cages for $2 \mathrm{hr}$, during which activity was monitored. Then, animals received an injection with saline $(1.0 \mathrm{ml} / \mathrm{kg}$, s.c. or i.p., depending on the route of administration of the challenge drug), and activity was monitored for $1 \mathrm{hr}$. Subsequently, animals were injected with amphetamine (1 mg/kg, i.p.), cocaine $(15 \mathrm{mg} / \mathrm{kg}$, i.p.), the dopamine D1 receptor agonist SKF-82958 (1 mg/kg, s.c.), the dopamine D2 receptor agonist quinpirole $(0.5 \mathrm{mg} / \mathrm{kg}$, s.c.), or the nonselective dopamine agonist apomorphine $(0.3 \mathrm{mg} / \mathrm{kg}$, s.c.). To examine the time course of amphetamine sensitization, locomotor challenges with amphetamine were performed $3 \mathrm{~d}$, 1 week, or 3 weeks after treatment. To examine the occurrence of long-term cross-sensitization to cocaine, SKF82958, quinpirole, and apomorphine, locomotor challenges with these drugs were performed 3 weeks after treatment. The challenge doses of the drugs represent the doses used previously to investigate dopaminergic mechanisms involved in the expression of locomotor sensitization induced by repeated amphetamine treatment (Vanderschuren et al., 1999a). Animals were challenged only once. All drugs were dissolved in sterile saline.

Determination of neurotransmitter release. Three days or 3 weeks after treatment, rats pre-exposed to saline or amphetamine were decapitated, and nucleus accumbens, caudate putamen, and medial prefrontal cortex were rapidly dissected. Tissue slices $(0.3 \times 0.3 \times 1 \mathrm{~mm})$ were prepared using a McIlwain tissue chopper and superfused as described previously (Schoffelmeer et al., 1994; Nestby et al., 1997). Slices (pooled tissue of two to three rats) were washed twice with Krebs'-Ringer's bicarbonate medium containing (in mM) $121 \mathrm{NaCl}, 1.87 \mathrm{KCl}, 1.17 \mathrm{KH}_{2} \mathrm{PO}_{4}, 1.17$ $\mathrm{MgSO}_{4}, 1.22 \mathrm{CaCl}_{2}, 25 \mathrm{NaHCO}_{3}$, and $10 \mathrm{D}-(+)$-glucose, and subsequently incubated for $15 \mathrm{~min}$ in this medium under a constant atmosphere of $95 \% \mathrm{O}_{2}-5 \% \mathrm{CO}_{2}$ at $37^{\circ} \mathrm{C}$. After preincubation, the slices were rapidly washed and incubated for $15 \mathrm{~min}$ in $2.5 \mathrm{ml}$ of medium containing $5 \mu \mathrm{Ci}\left[{ }^{3} \mathrm{H}\right]$ dopamine and $2 \mu \mathrm{Ci}\left[{ }^{14} \mathrm{C}\right]$ choline, under an atmosphere of
$95 \% \mathrm{O}_{2}-5 \% \mathrm{CO}_{2}$ at $37^{\circ} \mathrm{C}$. Because the nucleus accumbens and medial prefrontal cortex have a dense noradrenergic innervation, $3 \mu \mathrm{M}$ desipramine was added during incubation to prevent accumulation of $\left[{ }^{3} \mathrm{H}\right]$ dopamine in noradrenergic nerve terminals. After labeling, the slices were rapidly washed and transferred to each of 24 chambers of a superfusion apparatus ( $\sim 4 \mathrm{mg}$ of tissue in $0.2 \mathrm{ml}$ volume per chamber) and superfused $(0.20 \mathrm{ml} / \mathrm{min})$ with medium gassed with $95 \% \mathrm{O}_{2}-5 \% \mathrm{CO}_{2}$ at $37^{\circ} \mathrm{C}$.

In each experiment, neurotransmitter release from slices of saline- and amphetamine-pretreated rats was studied simultaneously in 24 parallel superfusion chambers. The superfusate was collected as $10 \mathrm{~min}$ samples after $40 \mathrm{~min}$ of superfusion $(t=40 \mathrm{~min}) . \mathrm{Ca}^{2+}$-dependent neurotransmitter release was induced during superfusion by exposing the slices to electrical biphasic block pulses $(1 \mathrm{~Hz}, 30 \mathrm{~mA}, 2 \mathrm{msec}$ pulses for nucleus accumbens and caudate putamen slices; and $1 \mathrm{~Hz}, 15 \mathrm{~mA}, 2 \mathrm{msec}$ pulses for medial prefrontal cortex slices) for $10 \mathrm{~min}$ at $t=50 \mathrm{~min}$ (electrical field stimulation).

The radioactivity remaining at the end of the experiment was extracted from the tissue with $0.1 \mathrm{~N} \mathrm{HCl}$. The radioactivity in superfusion fractions and tissue extracts was determined by liquid scintillation counting. The efflux of radioactivity during each collection period was expressed as a percentage of the amount of radioactivity in the slices at the beginning of the respective collection period. The electrically evoked release of neurotransmitter was calculated by subtracting the spontaneous efflux of radioactivity from the total overflow of radioactivity during stimulation and the next $10 \mathrm{~min}$. A linear decline from the $10 \mathrm{~min}$ interval before to that $20-30 \mathrm{~min}$ after the start of stimulation was assumed for calculation of the spontaneous efflux of radioactivity. The release evoked was expressed as percentage of the content of radioactivity of the slices at the start of the stimulation period.

Determination of hypothalamus-pituitary-adrenal axis activity. After a post-treatment interval of $3 \mathrm{~d}, 1$ week, or 3 weeks, saline- or amphetamine-pretreated rats were injected with amphetamine $(1 \mathrm{mg} / \mathrm{kg}$, i.p.), placed back into their home cages, and decapitated 20 min later. Trunk blood was collected in ice-cold heparin-coated tubes and centrifugated $\left(1000 \times \mathrm{g}, 15 \mathrm{~min}, 4^{\circ} \mathrm{C}\right)$. Aliquots of plasma were stored at $-20^{\circ} \mathrm{C}$ until assayed. ACTH concentrations were measured as described previously (Van Oers et al., 1992) using antiserum 8514 against the midportion of ACTH (Kovacs and Makara, 1988). Synthetic rat ACTH was used as a standard. The sensitivity of the assay was $10 \mathrm{pg} / \mathrm{ml}$ plasma $(0.5 \mathrm{pg} /$ tube). Plasma ACTH concentrations were expressed as $\mathrm{pg} / \mathrm{ml}$ plasma. Plasma corticosterone levels were determined by radioimmunoassay (ICN Biochemicals, Costa Mesa, CA) and expressed as nanograms per milliliter plasma. The sensitivity of the assay was $0.7 \mathrm{ng} / \mathrm{ml}$ plasma.

Radiochemicals and drugs. $\left[{ }^{3} \mathrm{H}\right]$ Dopamine $(47 \mathrm{Ci} / \mathrm{mmol})$ and $\left[{ }^{14} \mathrm{C}\right]$ choline $(15 \mathrm{mCi} / \mathrm{mmol})$ were purchased from the Radiochemical Center (Amersham Pharmacia Biotech, Buckinghamshire, UK). ACTH was purchased from Peninsula Laboratories (Belmont, CA). Desipramine, dopamine, and (-)-sulpiride were purchased from Sigma (St. Louis, MO). Morphine-HCl, (+)-amphetamine sulfate, cocaine- $\mathrm{HCl}$, and apomorphine-HCl were purchased from O.P.G. (Utrecht, The Netherlands), ( \pm -SKF-82958- $\mathrm{HBr}$ and (-)-quinpirole- $\mathrm{HCl}$ were from $\mathrm{Re}$ search Biochemicals (Natick, MA).

Statistics. Horizontal locomotor activity, expressed as distance traveled (in centimeters) was calculated in 10 min blocks. Locomotor activity was analyzed using two-factor repeated-measures ANOVA for time block and pretreatment. Post hoc comparisons were performed using StudentNewman-Keuls tests. In vitro neurotransmitter release and plasma ACTH and corticosterone concentrations were calculated as percentage of values from saline-pretreated rats in the respective experiment. Observations of different experiments were pooled and analyzed using one-way ANOVA.

\section{RESULTS}

\section{Time-dependent locomotor sensitization to amphetamine}

The locomotor effects of amphetamine ( $1 \mathrm{mg} / \mathrm{kg}$, i.p.) in salineand amphetamine-pretreated rats after various post-treatment intervals are presented in Figure $1 A-C$. The locomotor effect of amphetamine was enhanced in rats pre-exposed to amphetamine at $3 \mathrm{~d}, 1$ week, and 3 weeks after treatment, but to a different degree. Three days after exposure, the locomotor effects of amphetamine were only marginally affected by amphetamine pretreatment (pretreatment, $F_{(1,44)}=0.04 ; \mathrm{NS}$; pretreatment $\times$ time, 

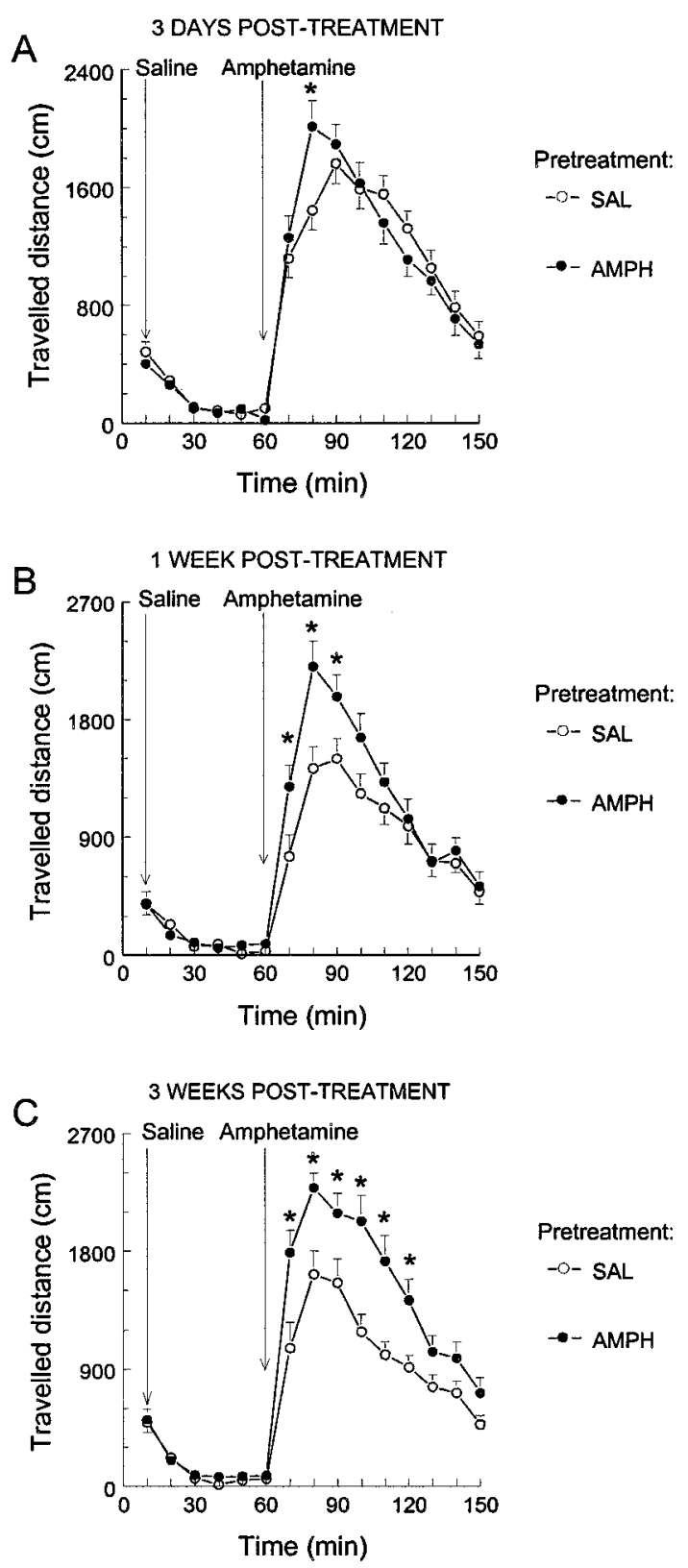

Figure 1. Locomotor responses to amphetamine $(1 \mathrm{mg} / \mathrm{kg}$, i.p.) in rats pretreated with amphetamine $[A M P H ; 1 \times 5 \mathrm{mg} / \mathrm{kg}$, i.p.; $n=22(A) ; n=$ $16(B) ; n=14(C)$; filled circles] or saline [SAL; $n=24(A) ; n=16(B)$; $n=15(C)$; open circles $] 3 \mathrm{~d}(A), 1$ week $(B)$, or 3 weeks $(C)$ after treatment. After $2 \mathrm{hr}$ habituation to the test cages, the animals were injected with saline ( $1 \mathrm{ml} / \mathrm{kg}$, i.p.) and $1 \mathrm{hr}$ later with amphetamine, after which activity was monitored for $1.5 \mathrm{hr}$. Data are expressed as mean \pm SEM traveled distance (in centimeters) per 10 min interval. ${ }^{*} p<0.05$, different from saline-pretreated rats (Student-Newman-Keuls).

$\left.F_{(8,352)}=3.29 ; p<0.01\right)$, sensitization being evident during the second 10 min time block only (Fig. $1 A$ ). One week after treatment, a more marked amphetamine pretreatment effect was found (pretreatment, $F_{(1,30)}=3.45 ; p=0.07$;) pretreatment $\times$ time, $\left.F_{(8,240)}=3.82 ; p<0.0001\right)$. In amphetamine-pre-exposed rats, the locomotor effects of amphetamine were enhanced during the first three 10 min time blocks (Fig. 1B). A clear-cut sensitization of the locomotor effects of amphetamine in amphetaminepre-exposed animals was observed 3 weeks after treatment (pretreatment, $F_{(1,27)}=11.48 ; p<0.01$; pretreatment $\times$ time,
$\left.F_{(8,216)}=2.58 ; p<0.05\right)$. Post hoc analysis showed a significant enhancement of amphetamine-induced hyperlocomotion during the first six 10 min time blocks (Fig. 1C). Pretreatment with amphetamine did not result in altered locomotion during the habituation phases (data not shown) and the challenges with saline, irrespective of the post-treatment interval at which testing was performed (Fig. $1 A-C$ ).

\section{Long-term cross-sensitization to cocaine and dopamine receptor agonists}

The long-term effects of a single pre-exposure to $5 \mathrm{mg} / \mathrm{kg}$ amphetamine on locomotor activity induced by cocaine and dopamine receptor agonists are presented in Figure 2. Three weeks after treatment, amphetamine-pre-exposed rats were sensitized to the locomotor effects of cocaine $(15 \mathrm{mg} / \mathrm{kg}$, i.p.) (pretreatment, $F_{(1,13)}=4.49 ; p=0.05$; pretreatment $\times$ time, $F_{(8,104)}=2.41 ; p<$ 0.05). Post hoc analysis revealed a significant enhancement of the locomotor effect of cocaine during three 10 min time blocks (Fig. $2 A$ ). In animals pretreated with amphetamine, the locomotor effect of the D1 receptor agonist SKF-82958 was altered. The overall locomotor effect of SKF-82958 appeared not to be affected at all by amphetamine pretreatment (total distance traveled, $14053 \pm 2919 \mathrm{~cm}$ in saline-pre-exposed rats and $13794 \pm 3223 \mathrm{~cm}$ in amphetamine-pre-exposed rats; pretreatment, $F_{(1,30)}=0.00 ;$ NS). However, the time course of SKF-82958 locomotion was altered in amphetamine-pre-exposed animals (pretreatment $\times$ time, $\left.F_{(14,420)}=3.48 ; p<0.0001\right)$; post hoc tests revealed a significant increase in the locomotor effect of SKF82958 in amphetamine-pretreated rats during the first two $10 \mathrm{~min}$ time blocks (Fig. 2B). When saline- and amphetamine-pretreated rats were challenged with the D2 receptor agonist quinpirole, a tendency toward sensitization in amphetamine-pretreated rats was found (pretreatment, $F_{(1,12)}=4.24 ; p=0.06$; pretreatment $\times$ time, $F_{(23,276)}=0.85$; NS) (Fig. $2 C$ ). The locomotor effects of the nonselective dopamine receptor agonist apomorphine did not differ between rats pretreated with saline and amphetamine (pretreatment, $F_{(1,14)}=0.36$; NS; pretreatment $\times$ time, $F_{(8,112)}=$ 1.81; NS) (Fig. 2D). Amphetamine pre-exposure did not result in altered locomotion during the habituation phases (data not shown) and the challenges with saline (Fig. 2A-D).

\section{Time-dependent adaptive changes in forebrain dopamine and acetylcholine neurotransmission}

Studying the electrically evoked release of $\left[{ }^{3} \mathrm{H}\right]$ dopamine and $\left[{ }^{14} \mathrm{C}\right]$ acetylcholine, the effect of amphetamine pretreatment on the reactivity of dopaminergic and cholinergic nerve terminals in nucleus accumbens, caudate putamen, and medial prefrontal cortex toward depolarization was investigated $3 \mathrm{~d}$ and 3 weeks after treatment. In slices of saline-pretreated rats, the electrically stimulated $\left[{ }^{3} \mathrm{H}\right]$ dopamine release in excess of spontaneous $\left[{ }^{3} \mathrm{H}\right]$ efflux in slices of nucleus accumbens, caudate putamen, and medial prefrontal cortex amounted to $1.6 \pm 0.1,2.4 \pm 0.2$, and $3.8 \pm$ $0.2 \%$ of total tissue radioactivity, respectively. The electrically stimulated $\left[{ }^{14} \mathrm{C}\right]$ acetylcholine release in excess of spontaneous $\left[{ }^{14} \mathrm{C}\right]$ efflux in slices of nucleus accumbens and caudate putamen, respectively, amounted to $4.2 \pm 0.3$ and $6.0 \pm 0.4 \%$ of total tissue radioactivity. Because the electrically evoked release of $\left[{ }^{14} \mathrm{C}\right]$ acetylcholine from medial prefrontal cortex slices hardly exceeded the spontaneous efflux of radioactivity, $\left[{ }^{14} \mathrm{C}\right]$ acetylcholine release data from medial prefrontal cortex slices are not presented.

As shown in Figure 3, the responsiveness of all types of nerve terminals investigated was increased at both time points as a 

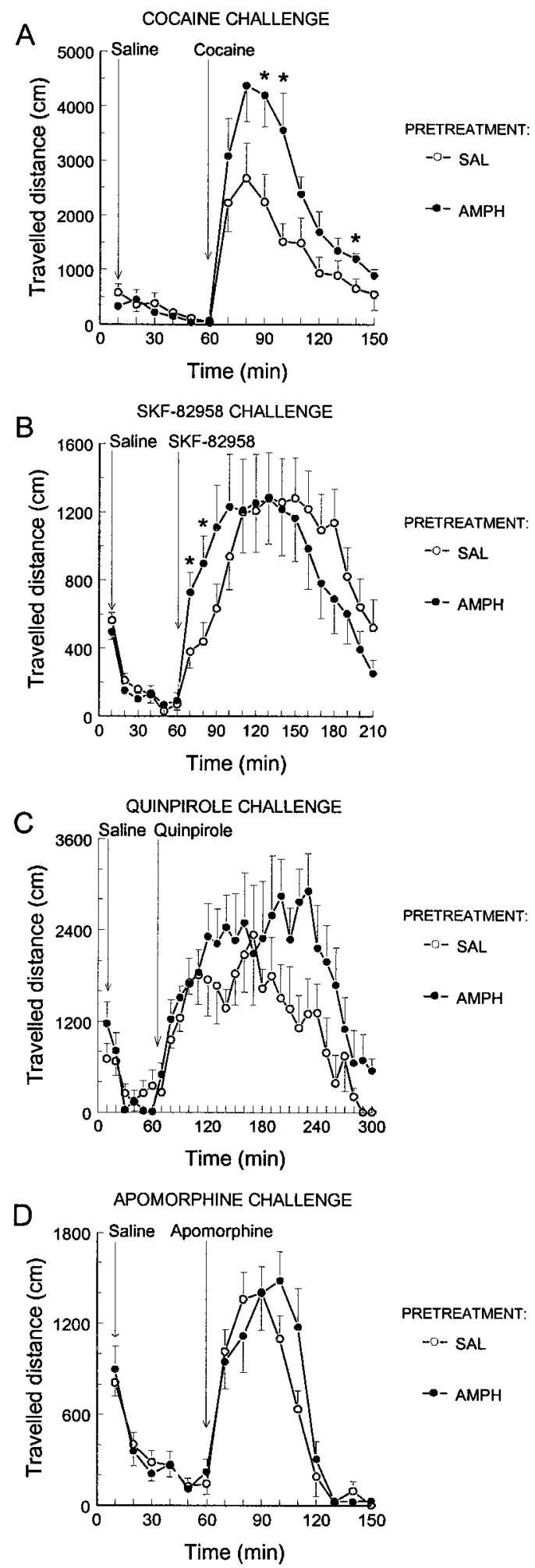

Figure 2. Locomotor responses to cocaine ( $15 \mathrm{mg} / \mathrm{kg}$, i.p.; $A)$, SKF-82958 $(1 \mathrm{mg} / \mathrm{kg}$, s.c.; $B)$, quinpirole $(0.5 \mathrm{mg} / \mathrm{kg}$, s.c.; $C)$, or apomorphine $(0.3$ $\mathrm{mg} / \mathrm{kg}$, s.c.; $D)$ in rats pretreated with amphetamine $[A M P H ; 1 \times 5 \mathrm{mg} / \mathrm{kg}$, i.p.; $n=8(A) ; n=16(B) ; n=7(C) ; n=8(D)$; filled circles] or saline $[S A L ; n=7(A) ; n=16(B) ; n=7(C) ; n=8(D)$; open circles $] 3$ weeks after treatment. After $2 \mathrm{hr}$ habituation to the test cages, the animals were injected with saline $(1 \mathrm{ml} / \mathrm{kg}$, s.c. or i.p.) and $1 \mathrm{hr}$ later with the challenge drug, after which activity was monitored for $1.5-4 \mathrm{hr}$. Data are expressed as mean \pm SEM traveled distance (in centimeters) per 10 min interval. ${ }^{*} p<$ 0.05 , different from saline-pretreated rats (Student-Newman-Keuls). consequence of amphetamine pretreatment. In nucleus accumbens slices, the amphetamine-induced hyperreactivity of dopaminergic nerve terminals increased over time ( $3 \mathrm{~d}$ vs 3 weeks, $\left.F_{(1,76)}=4.41 ; p<0.05\right)$, from a $41 \%$ increase $3 \mathrm{~d}\left(F_{(1,63)}=12.35\right.$; $p<0.001)$ to a $69 \%$ increase 3 weeks $\left(F_{(1,83)}=39.31 ; p<0.0001\right)$ after treatment. On the other hand, the responsiveness of cholinergic nerve terminals in nucleus accumbens slices as a result of pretreatment with amphetamine was enhanced to a similar degree at both time points: $39 \%$ at $3 \mathrm{~d}\left(F_{(1,65)}=12.21 ; p<0.001\right)$ and $41 \%$ at 3 weeks $\left(F_{(1,85)}=32.64 ; p<0.0001\right)$ after treatment (Fig. 3A). The neuroadaptive effects of amphetaminepretreatment observed in caudate putamen were comparable but smaller than those found in the accumbens. The hyperresponsiveness of dopaminergic nerve terminals increased, from an enhancement of $20 \%$ at $3 \mathrm{~d}\left(F_{(1,58)}=6.97 ; p<0.05\right)$ to $34 \%$ at 3 weeks $\left(F_{(1,55)}=16.50 ; p<0.001\right)$ after treatment, but this time effect was not significant ( $3 \mathrm{~d}$ vs 3 weeks, $F_{(1,56)}=2.11$; NS). Amphetamine-induced hyperreactivity of cholinergic nerve terminals in caudate putamen slices was comparable at both time points: $37 \%$ at $3 \mathrm{~d}\left(F_{(1,55)}=16.82 ; p<0.001\right)$ and $34 \%$ at 3 weeks $\left(F_{(1,66)}=12.67 ; p<0.001\right)$ after treatment (Fig. $\left.3 B\right)$. With regard to hyperresponsiveness of dopaminergic nerve terminals in medial prefrontal cortex slices, a picture opposite from that observed in accumbens and caudate slices emerged. As a result of preexposure to amphetamine, neuronal responsiveness was increased at $3 \mathrm{~d}$ after treatment by $78 \%\left(F_{(1,30)}=38.14 ; p<\right.$ $0.0001)$, and this effect significantly declined ( $3 \mathrm{~d}$ vs 3 weeks, $\left.F_{(1,37)}=12.90 ; p<0.01\right)$ to a $36 \%$ increase at 3 weeks after treatment $\left(F_{(1,41)}=24.01 ; p<0.0001\right)$ (Fig. 3C).

\section{Time-dependent sensitization of the hypothalamus-pituitary-adrenal axis}

The effects of amphetamine $(1 \mathrm{mg} / \mathrm{kg}$, i.p.) on plasma concentrations of $\mathrm{ACTH}$ and corticosterone in rats pretreated with saline or amphetamine are presented in Figure 4, $A$ and $B$, respectively. There was a considerable variation between experiments regarding the magnitude of neuroendocrine parameters determined. In saline-pretreated rats, amphetamine-induced plasma concentrations of ACTH varied between $51.7 \pm 9.4$ and $148.4 \pm 11.0 \mathrm{pg} / \mathrm{ml}$ and plasma corticosterone between $43.3 \pm 5.4$ and $121.2 \pm 15.1$ $\mathrm{ng} / \mathrm{ml}$. Despite this variation, there were clear-cut effects of amphetamine pre-exposure on hypothalamus-pituitary-adrenal axis reactivity to amphetamine. Three days after treatment, no effect of amphetamine pre-exposure on the amphetamineinduced increase in the secretion of $\operatorname{ACTH}\left(F_{(1,8)}=0.03\right.$; NS) (Fig. $4 A)$ and corticosterone $\left(F_{(1,8)}=0.21\right.$; NS) (Fig. $4 B$ ) was observed. One week after treatment, the amphetamine-induced increase in both ACTH and corticosterone secretion were significantly augmented in amphetamine-pretreated rats; the secretion of ACTH was increased by $43 \%\left(F_{(1,9)}=7.06 ; p<0.05\right)($ Fig. $4 A)$ and the secretion of corticosterone by $84 \%\left(F_{(1,8)}=8.31 ; p<\right.$ 0.05 ) (Fig. 4B). Comparable effects were observed at 3 weeks after treatment, i.e., in animals pretreated with amphetamine, amphetamine-induced ACTH concentrations were increased by $34 \%\left(F_{(1,9)}=5.50 ; p<0.05\right)$ (Fig. $\left.4 A\right)$ and corticosterone concentrations by $73 \%\left(F_{(1,11)}=18.03 ; p<0.01\right)($ Fig. $4 B)$.

\section{DISCUSSION}

The main finding in the present study is that a single exposure to amphetamine ( $5 \mathrm{mg} / \mathrm{kg}$, i.p.) causes long-lasting behavioral sensitization associated with neurochemical and neuroendocrine adaptations. Amphetamine-induced behavioral sensitization was 

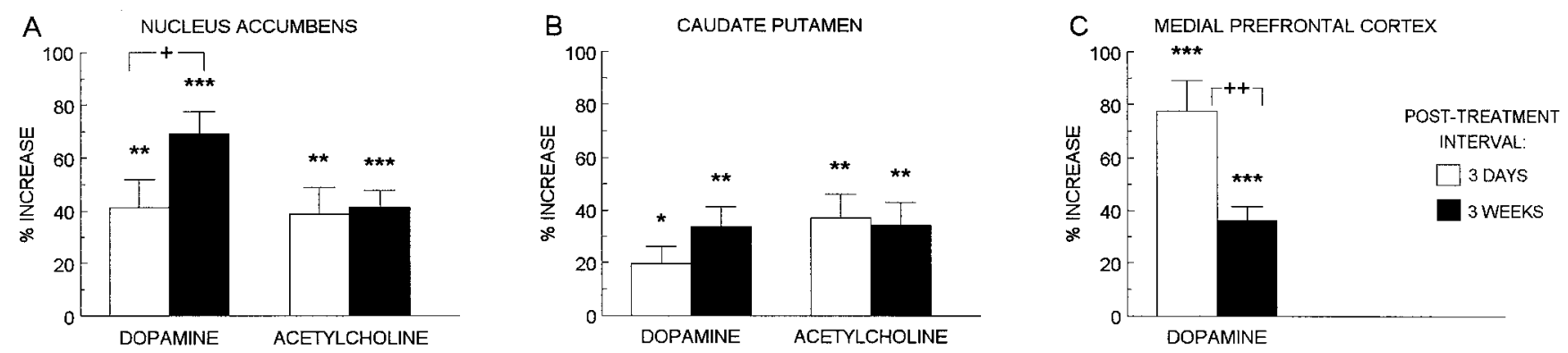

Figure 3. A, Enhancement of the electrically evoked release of $\left[{ }^{3} \mathrm{H}\right]$ dopamine and $\left[{ }^{14} \mathrm{C}\right]$ acetylcholine from superfused nucleus accumbens slices of rats as a result of pre-exposure to amphetamine $(1 \times 5 \mathrm{mg} / \mathrm{kg}$, i.p.) $3 \mathrm{~d}$ (open bars) or 3 weeks ( filled bars) after treatment. $B$, Enhancement of the electrically evoked release of $\left[{ }^{3} \mathrm{H}\right]$ dopamine and $\left[{ }^{14} \mathrm{C}\right]$ acetylcholine from superf used caudate putamen slices of rats as a result of pre-exposure to amphetamine $(1 \times$ $5 \mathrm{mg} / \mathrm{kg}$, i.p.) $3 \mathrm{~d}$ (open bars) or 3 weeks (filled bars) after treatment. $C$, Enhancement of the electrically evoked release of [ $\left.{ }^{3} \mathrm{H}\right]$ dopamine from superfused medial prefrontal cortex slices of rats as a result of pre-exposure to amphetamine $(1 \times 5 \mathrm{mg} / \mathrm{kg}$, i.p.) $3 \mathrm{~d}$ (open bars) or 3 weeks ( filled bars) after treatment. Data are expressed as percent increase above electrically evoked release in slices of saline-pretreated rats and represent means \pm SEM of $15-45$ observations. ${ }^{*} p<0.05 ;{ }^{* *} p<0.001 ; * * * p<0.0001$, different from saline pretreatment (ANOVA) $+p<0.05 ;++p<0.01,3 \mathrm{~d}$ after treatment differs from 3 weeks after treatment (ANOVA).

expressed in a context-independent manner and gradually developed after pretreatment, with sensitization being most pronounced at 3 weeks after treatment. Moreover, a long-lasting cross-sensitization to cocaine and a tendency toward crosssensitization to the dopamine D2 receptor agonist quinpirole was found after pre-exposure to amphetamine. Amphetamine pretreatment caused a time-dependent hyperreactivity toward depolarization of dopaminergic nerve terminals in the nucleus accumbens, caudate putamen, and medial prefrontal cortex and cholinergic nerve terminals in nucleus accumbens and caudate putamen. In addition, a delayed hyperreactivity of the hypothalamus-pituitary-adrenal axis toward an amphetamine challenge was induced by amphetamine pretreatment. Together, the effects of a single exposure to amphetamine closely resemble those we (Nestby et al., 1997; Schmidt et al., 1999; Vanderschuren et al., 1999a,b) and others (for review, see Pierce and Kalivas, 1997) have found previously after repeated amphetamine pretreatment. We therefore conclude that a single exposure to amphetamine is sufficient to induce long-lasting behavioral, neurochemical, and neuroendocrine sensitization in rats.

Long-term behavioral sensitization evoked by a single psychostimulant exposure has been reported previously, but the present study is the first to show that this can occur in a contextindependent manner, meaning that pretreatment and challenge injections were administered in separate environments. In this respect, it is important to note that during neither habituation phases nor saline challenges locomotor activity differed between amphetamine- and saline-pretreated rats. This indicates that amphetamine pretreatment did not induce changes in basal or novelty-induced locomotion or a conditioned psychomotor response to the injection. Therefore, the observed locomotor sensitization most likely represents a nonassociative increase in the sensitivity to the locomotor effects of psychostimulant drugs, as a result of neuroadaptive changes induced by amphetamine pretreatment.

With regard to locomotor sensitization, the pattern of effects evoked by a single pre-exposure to amphetamine strikingly resembled that induced by repeated amphetamine pretreatment. Thus, the magnitude of amphetamine-induced sensitization to the locomotor effects of amphetamine gradually increased with prolonged withdrawal (i.e., between $3 \mathrm{~d}$ and 3 weeks after treatment), which has also been observed after repeated amphetamine pretreatment (Kolta et al., 1985; Paulson et al., 1991; Vanderschuren et al., 1999b). In addition, just like repeated amphetamine pretreatment (Conway and Uretsky, 1982; Robinson, 1984; Kalivas and Weber, 1988; Vanderschuren et al., 1999a,b), single amphetamine caused cross-sensitization to cocaine but not to morphine and apomorphine. Also, both regimens induced crosssensitization to quinpirole but to different degrees, i.e., a robust sensitization after repeated amphetamine (Ujike et al., 1990; Vanderschuren et al., 1999a), whereas cross-sensitization to quinpirole after single amphetamine just failed to reach statistical
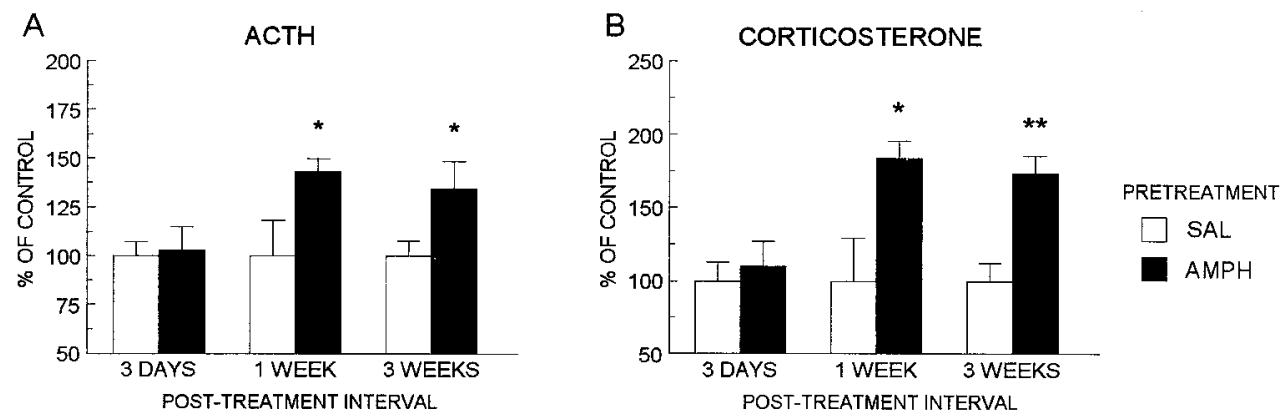

Figure 4. Plasma concentrations of $\operatorname{ACTH}(A)$ and corticosterone $(B)$ induced by a challenge with amphetamine in rats pretreated with amphetamine $(A M P H ; 1 \times 5 \mathrm{mg} / \mathrm{kg}$, i.p.; filled bars) or saline $(S A L ;$ open bars $) 3 \mathrm{~d}, 1$ week, or 3 weeks after treatment. Groups of rats $(n=4-6)$ were injected with amphetamine $(1 \mathrm{mg} / \mathrm{kg}$, i.p.) in their home cages and decapitated $20 \mathrm{~min}$ later. Trunk blood was collected, and plasma ACTH and corticosterone concentrations were determined by radioimmunoassay. Results are presented as percentage of plasma concentrations in saline-pretreated rats. Values represent means \pm SEM. ${ }^{*} p<0.05 ;{ }^{*} p<0.01$, different from saline pretreatment (ANOVA). 
significance. There was a slight difference between single and repeated amphetamine with regard to the onset of the locomotor response to SKF-82958, which appeared to be somewhat faster after single amphetamine but slower after repeated amphetamine (Vanderschuren et al., 1999a). The reason for this discrepancy remains to be clarified.

Neuroadaptive changes in mesotelencephalic dopaminergic projections play a prominent role in the induction and expression of amphetamine sensitization. Whereas sensitization can be induced by microinjection of amphetamine into the ventral tegmental area, the cell body region of the mesolimbic dopaminergic system (Kalivas and Weber, 1988; Perugini and Vezina, 1994; Cador et al., 1995), its expression is associated with timedependent adaptations in forebrain dopaminergic terminal areas, such as the nucleus accumbens and caudate putamen (Kolta et al., 1985; Robinson et al., 1988; Wolf et al., 1993; Paulson and Robinson, 1995). Dopaminergic neurotransmission in nucleus accumbens and caudate putamen plays a critical role in the locomotor and stereotypic effects of psychostimulant drugs, respectively (Kelly et al., 1975; Pijnenburg et al., 1975; Sharp et al., 1987; Delfs et al., 1990). Therefore, it is likely that hyperresponsiveness of striatal dopaminergic nerve terminals plays a major role in the expression of psychostimulant sensitization. Indeed, in particular, after extended post-treatment intervals ( $>1$ week), there appears to be a close correlation between hyperreactivity of striatal dopaminergic neurotransmission and expression of behavioral sensitization. On the other hand, inconsistencies in the occurrence of these phenomena have been reported after short post-treatment intervals (for review, see Pierce and Kalivas, 1997). In the present study, a single amphetamine exposure induced hyperreactivity toward electrical depolarization of dopaminergic nerve terminals in the nucleus accumbens and caudate putamen, an effect that increased between $3 \mathrm{~d}$ and 3 weeks after treatment. This is consistent with findings reported after repeated amphetamine pretreatment, using both in vitro and in vivo preparations (Kolta et al., 1985; Wolf et al., 1993; Paulson and Robinson, 1995; Nestby et al., 1997). We observed a strong relationship between hyperreactivity of accumbens dopaminergic neurotransmission and expression of locomotor sensitization to amphetamine, in that both phenomena gradually intensified with prolonged withdrawal. On the other hand, at $3 \mathrm{~d}$ after treatment, accumbens dopaminergic nerve terminals were markedly hyperreactive, but locomotor sensitization to amphetamine was only marginal. A possible explanation for this could be that the expression of amphetamine sensitization depends on the balance between dopamine neurotransmission in the nucleus accumbens and medial prefrontal cortex. Thus, consistent with the effects of repeated amphetamine pretreatment (Stephans and Yamamoto, 1995; L. J. M. J. Vanderschuren, unpublished observations), we found that a single exposure to amphetamine resulted in an enduring hyperreactivity of medial prefrontal dopaminergic nerve terminals. Remarkably, however, hyperreactivity of medial prefrontal dopaminergic nerve terminals decreased with prolonged withdrawal, displaying an opposite time course to the hyperreactivity of accumbens dopaminergic terminals. Increased dopaminergic neurotransmission in the medial prefrontal cortex is known to inhibit accumbens dopaminergic neurotransmission, as well as psychostimulant-induced locomotion (Louilot et al., 1989; Vezina et al., 1991). It might therefore be that, especially after a short post-treatment interval, hypersensitivity of medial prefrontal dopaminergic terminals exerts an inhibitory influence on the expression of amphetamine sensitization. Previous behav- ioral and neurochemical studies (Banks and Gratton, 1995; Prasad et al., 1999) support such a modulatory role of mesocortical dopaminergic neurotransmission in the induction and expression of psychostimulant sensitization.

A single amphetamine exposure evoked enduring hyperreactivity of cholinergic nerve terminals in nucleus accumbens and caudate putamen, an effect that also occurred after repeated amphetamine pretreatment (Nestby et al., 1997). Interestingly, an increase in striatal acetylcholine release has been reported to correlate with the expression of amphetamine sensitization (Bickerdike and Abercrombie, 1997). In addition, in striatal slices of morphine-sensitized rats, enhanced cholinergic neurotransmission increased dopamine release through activation of presynaptic muscarinic receptors (Schoffelmeer et al., 1995). Because striatal dopamine release can be stimulated by activation of presynaptic muscarinic (Schoffelmeer et al., 1995; Smolders et al., 1997) and nicotinic (Rowell et al., 1987; Mifsud et al., 1989; Marshall et al., 1997) receptors, hyperreactivity of cholinergic neurons may contribute to the expression of behavioral sensitization through a sustained stimulatory effect on striatal dopaminergic neurotransmission. Furthermore, interactions between dopaminergic and cholinergic input into efferent striatal neurons (Di Chiara et al., 1994) could also contribute to the expression of behavioral sensitization.

The neuroendocrine consequences of a single exposure to amphetamine were also similar to those after repeated amphetamine, i.e., in amphetamine-pretreated animals a hypersecretion of ACTH and corticosterone was found after an amphetamine challenge 3 weeks but not 3 d after treatment (Schmidt et al., 1999; E. D. Schmidt, unpublished observations). Long-lasting sensitization of the ACTH and corticosterone response to amphetamine may be involved in the autonomic and affective consequences of amphetamine exposure, but a crucial role in the expression of psychostimulant sensitization has been questioned (Badiani et al., 1995; Johnson et al., 1995; Prasad et al., 1996; Schmidt et al., 1999). On the other hand, the glucocorticoid receptor antagonist mifepristone (RU486) blocked the expression of amphetamine sensitization (De Vries et al., 1996). Also, glucocorticoid receptor activation enhances dopamine neurotransmission (Ronken et al., 1994; Piazza et al., 1996; Schoffelmeer et al., 1997), whereas corticosterone may augment the locomotor effects of psychostimulant drugs (Cador et al., 1993; Marinelli et al., 1994, 1997; but see Badiani et al., 1995). Therefore, a facilitatory role for central corticosteroid receptors in the expression of amphetamine sensitization cannot be excluded.

Together, the present data suggest that a single exposure to amphetamine is sufficient to induce long-lasting sensitization at the behavioral, neurochemical, and neuroendocrine levels. Repeated exposure to drugs of abuse induces a complex pattern of time-dependent adaptations in a variety of transmitter systems and brain regions, ultimately resulting in long-lasting behavioral sensitization (for review, see White et al., 1995; Pierce and Kalivas, 1997; Wolf, 1998). It has been hypothesized that this cascade of neuroadaptations is driven by phasic alterations in gene expression. Mechanistic similarities between behavioral sensitization and other forms of neuronal plasticity, such as long-term memory, have been suggested. For instance, just like long-term memory (Tully, 1998), the induction of long-lasting behavioral sensitization requires novel protein synthesis (Karler et al., 1993; Shimosato and Saito, 1993; Sorg and Ulibarri, 1995), structural changes at relevant synapses (Robinson and Kolb, 1997), and is most effectively induced by intermittent stimulation (Post, 1980; 
Robinson and Becker, 1986; Stewart and Badiani, 1993; Vanderschuren et al., 1997). The present study adds another similarity between long-term memory and long-lasting behavioral sensitization, in that both phenomena and their associated neuroadaptations can be induced by a single pertinent stimulus.

\section{REFERENCES}

Anagnostaras SG, Robinson TE (1996) Senzitization to the psychomotor stimulant effects of amphetamine: modulation by associative learning. Behav Neurosci 110:1397-1414.

Badiani A, Morano MI, Akil H, Robinson TE (1995) Circulating adrenal hormones are not necessary for the development of sensitization to the psychomotor activating effects of amphetamine. Brain Res 673:13-24.

Banks KE, Gratton A (1995) Possible involvement of medial prefrontal cortex in amphetamine-induced sensitization of mesolimbic dopamine function. Eur J Pharmacol 282:157-167.

Bickerdike MJ, Abercrombie ED (1997) Striatal acetylcholine release correlates with behavioral sensitization in rats withdrawn from chronic amphetamine. J Pharmacol Exp Ther 282:818-826.

Cador M, Dulluc J, Mormède P (1993) Modulation of the locomotor response to amphetamine by corticosterone. Neuroscience 56:981-988.

Cador M, Bjijou Y, Stinus L (1995) Evidence of a complete independence of the neurobiological substrates for the induction and expression of behavioral sensitization to amphetamine. Neuroscience 65:385-395.

Conway PG, Uretsky NJ (1982) Role of striatal dopaminergic receptors in amphetamine-induced behavioral facilitation. J Pharmacol Exp Ther 221:650-655.

De Vries TJ, Schoffelmeer ANM, Tjon GHK, Nestby P, Mulder AH, Vanderschuren LJMJ (1996) Mifepristone prevents the expression of behavioural sensitization to amphetamine. Eur J Pharmacol 307:R3-R4.

De Vries TJ, Schoffelmeer ANM, Binnekade R, Mulder AH, Vanderschuren LJMJ (1998) Drug-induced reinstatement of heroin- and cocaine-seeking behaviour following long-term extinction is associated with expression of behavioural sensitization. Eur $\mathbf{J}$ Neurosci 10:3565-3571.

Delfs JM, Schreiber L, Kelley AE (1990) Microinjection of cocaine into the nucleus accumbens elicits locomotor activation in the rat. $\mathrm{J}$ Neurosci 10:303-310.

Di Chiara G, Morelli M, Consolo S (1994) Modulatory functions of neurotransmitters in the striatum: ACh/dopamine/NMDA interactions. Trends Neurosci 17:228-233.

Hoffman DC, Wise RA (1992) Locomotor-activating effects of the $\mathrm{D}_{2}$ agonist bromocriptine show environment-specific sensitization following repeated injections. Psychopharmacology 107:277-284.

Johnson DH, Svensson AI, Engel JA, Söderpalm B (1995) Induction but not expression of behavioural sensitization to nicotine in the rat is dependent on glucocorticoids. Eur J Pharmacol 276:155-164.

Kalivas PW, Alesdatter JE (1993) Involvement of $N$-methyl-D-aspartate receptor stimulation in the ventral tegmental area and amygdala in behavioral sensitization to cocaine. J Pharmacol Exp Ther 267:486-495.

Kalivas PW, Weber B (1988) Amphetamine injection into the ventral mesencephalon sensitizes rats to peripheral amphetamine and cocaine. J Pharmacol Exp Ther 245:1095-1102.

Karler R, Finnegan KT, Calder LD (1993) Blockade of behavioral sensitization to cocaine and amphetamine by inhibitors of protein synthesis. Brain Res 603:19-24.

Kelly PH, Seviour PW, Iversen SD (1975) Amphetamine and apomorphine responses in the rat following 6-OHDA lesions of the nucleus accumbens septi and corpus striatum. Brain Res 94:507-522.

Kolta MG, Shreve P, De Souza V, Uretsky NJ (1985) Time course of the development of the enhanced behavioral and biochemical responses to amphetamine after pretreatment with amphetamine. Neuropharmacology 24:823-829.

Kovacs KJ, Makara GB (1988) Corticosterone and dexamethasone act at different brain sites to inhibit adrenalectomy-induced adrenocorticotropin hypersecretion. Brain Res 474:205-210.

Li Y, Vartanian AJ, White FJ, Xue C-J, Wolf ME (1997) Effects of the AMPA receptor antagonist NBQX on the development and expression of behavioral sensitization to cocaine and amphetamine. Psychopharmacology 134:266-276.

Louilot A, Le Moal M, Simon H (1989) Opposite influences of dopami- nergic pathways to the prefrontal cortex or the septum on the dopaminergic transmission in the nucleus accumbens. An in vivo voltammetric study. Neuroscience 29:45-56.

Marinelli M, Piazza PV, Deroche V, Maccari S, Le Moal M, Simon H (1994) Corticosterone circadian secretion differentially facilitates dopamine-mediated psychomotor effect of cocaine and morphine. J Neurosci 14:2724-2731.

Marinelli M, Rougé-Pont F, Deroche V, Barrot M, De Jesus Oliveira C, Le Moal M, Piazza PV (1997) Glucocorticoids and behavioral effects of psychostimulants. I. Locomotor response to cocaine depends on basal levels of glucocorticoids. J Pharmacol Exp Ther 281:1392-1400.

Marshall DL, Redfern PH, Wonnacott S (1997) Presynaptic nicotinic modulation of dopamine release in the three ascending pathways studied by in vivo microdialysis: comparison of naive and chronic nicotinetreated rats. J Neurochem 68:1511-1519.

Mead AN, Stephens DN (1998) AMPA-receptors are involved in the expression of amphetamine-induced behavioural sensitisation, but not in the expression of amphetamine-induced conditioned activity in mice. Neuropharmacology 37:1131-1138.

Mifsud J-C, Hernandez L, Hoebel BG (1989) Nicotine infused into the nucleus accumbens increases synaptic dopamine as measured by in vivo microdialysis. Brain Res 478:365-367.

Nestby P, Vanderschuren LJMJ, De Vries TJ, Hogenboom F, Wardeh G, Mulder AH, Schoffelmeer ANM (1997) Ethanol, like psychostimulants and morphine, causes long-lasting hyperreactivity of dopamine and acetylcholine neurons of rat nucleus accumbens: possible role in behavioural sensitization. Psychopharmacology 133:69-76.

Paulson PE, Robinson TE (1995) Amphetamine-induced timedependent sensitization of dopamine-neurotransmission in the dorsal and ventral striatum: a microdialysis study in behaving rats. Synapse 19:56-65.

Paulson PE, Camp DM, Robinson TE (1991) Time course of transient behavioral depression and persistent behavioral sensitization in relation to regional brain monoamine concentrations during amphetamine withdrawal in rats. Psychopharmacology 103:480-492.

Peris J, Zahniser NR (1987) One injection of cocaine produces a longlasting increase in $\left[{ }^{3} \mathrm{H}\right]$-dopamine release. Pharmacol Biochem Behav 27:533-535

Perugini M, Vezina P (1994) Amphetamine administered to the ventral tegmental area sensitizes rats to the locomotor effects of nucleus accumbens amphetamine. J Pharmacol Exp Ther 270:690-696.

Piazza PV, Rougé-Pont F, Deroche V, Maccari S, Simon H, Le Moal M (1996) Glucocorticoids have state-dependent stimulant effects on the mesencephalic dopaminergic transmission. Proc Natl Acad Sci USA 93:8716-8720.

Pierce RC, Kalivas PW (1997) A circuitry model of the expression of behavioral sensitization to amphetamine-like psychostimulants. Brain Res Rev 25:192-216.

Pijnenburg AJJ, Honig WMM, Van Rossum JM (1975) Inhibition of D-amphetamine-induced locomotor activity by injection of haloperidol into the nucleus accumbens of the rat. Psychopharmacologia 41:87-95.

Post RM (1980) Intermittent versus continuous stimulation: effect of time interval on the development of sensitization or tolerance. Life Sci 26:1275-1282.

Prasad BM, Ulibarri C, Kalivas PW, Sorg BA (1996) Effect of adrenalectomy on the initiation and expression of cocaine-induced sensitization. Psychopharmacology 125:265-273.

Prasad BM, Hochstatter T, Sorg BA (1999) Expression of cocaine sensitization: regulation by the medial prefrontal cortex. Neuroscience 88:765-774

Robinson TE (1984) Behavioral sensitization: characterization of enduring changes in rotational behavior produced by intermittent injections of amphetamine in male and female rats. Psychopharmacology $84: 466-475$

Robinson TE, Becker JB (1986) Enduring changes in brain and behavior produced by chronic amphetamine administration: a review and evaluation of animal models of amphetamine psychosis. Brain Res Rev 11:157-198.

Robinson TE, Berridge KC (1993) The neural basis of drug craving: an incentive-sensitization theory of addiction. Brain Res Rev 18:247-291.

Robinson TE, Kolb B (1997) Persistent structural modifications in nucleus accumbens and prefrontal cortex neurons produced by previous experience with amphetamine. J Neurosci 17:8491-8497. 
Robinson TE, Becker JB, Presty SK (1982) Long-term facilitation of amphetamine-induced rotational behavior and striatal dopamine release produced by a single exposure to amphetamine: sex differences. Brain Res 253:231-241.

Robinson TE, Jurson PA, Bennett JA, Bentgen KM (1988) Persistent sensitization of dopamine neurotransmission in ventral striatum (nucleus accumbens) produced by previous experience with (+)-amphetamine: a microdialysis study in freely moving rats. Brain Res 462:211-222.

Robinson TE, Browman KE, Crombag HS, Badiani A (1998) Modulation of the induction or expression of psychostimulant sensitization by the circumstances surrounding drug administration. Neurosci Biobehav Rev 22:347-354.

Ronken E, Mulder AH, Schoffelmeer ANM (1994) Glucocorticoid and mineralocorticoid receptors differentially modulate cultured dopaminergic neurons of rat ventral mesencephalon. Eur J Pharmacol 263:149-156.

Rowell PP, Carr LA, Garner AC (1987) Stimulation of $\left[{ }^{3} \mathrm{H}\right]$ dopamine release by nicotine in rat nucleus accumbens. J Neurochem 49:1449-1454.

Schmidt ED, Tilders FJH, Binnekade R, Schoffelmeer ANM, De Vries TJ (1999) Stressor- or drug-induced sensitization of the corticosterone response is not critically involved in the long-term expression of behavioral sensitization to amphetamine. Neuroscience 92:343-352.

Schoffelmeer ANM, Hogenboom F, Mulder AH, Ronken E, Stoof JC, Drukarch B (1994) Dopamine displays an identical apparent affinity towards functional dopamine $\mathrm{D}_{1}$ and $\mathrm{D}_{2}$ receptors in rat striatal slices: possible implications for the regulatory role of $D_{2}$ receptors. Synapse 17:190-195.

Schoffelmeer ANM, Nestby P, Tjon GHK, Wardeh G, De Vries TJ, Vanderschuren LJMJ, Mulder AH (1995) Intermittent morphine treatment causes a protracted increase in cholinergic striatal neurotransmission measured ex vivo. Eur J Pharmacol 286:311-314.

Schoffelmeer ANM, De Vries TJ, Vanderschuren LJMJ, Tjon GHK, Nestby P, Wardeh G, Mulder AH (1997) Intermittent morphine administration induces a long-lasting synergistic effect of corticosterone on dopamine D1 receptor functioning in rats striatal GABA neurons. Synapse 25:381-388.

Sharp T, Zetterström T, Ljungberg T, Ungerstedt U (1987) A direct comparison of amphetamine-induced behaviours and regional brain dopamine release in the rat using intracerebral microdialysis. Brain Res 401:322-330.

Shimosato K, Saito T (1993) Suppressive effect of cycloheximide on behavioral sensitization to methamphetamine in mice. Eur J Pharmacol 234:67-75.

Smolders I, Bogaert L, Ebinger G, Michotte Y (1997) Muscarinic modulation of striatal dopamine, glutamate, and GABA release, as measured with in vivo microdialysis. J Neurochem 68:1942-1948.

Sorg BA, Ulibarri C (1995) Application of a protein synthesis inhibitor into the ventral tegmental area, but not the nucleus accumbens, prevents behavioral sensitization to cocaine. Synapse 20:217-224.

Stephans SE, Yamamoto BK (1995) Effect of repeated methamphetamine administrations on dopamine and glutamate efflux in rat prefrontal cortex. Brain Res 700:99-106.

Stewart J, Badiani A (1993) Tolerance and sensitization to the behavioral effects of drugs. Behav Pharmacol 4:289-312.

Stewart J, Druhan JP (1993) Development of both conditioning and sensitization of the behavioral activating effects of amphetamine is blocked by the non-competitive NMDA receptor antagonist, MK-801. Psychopharmacology 110:125-132.

Tully T (1998) Toward a molecular biology of memory: the light's coming on! Nature Neurosci 1:543-545.

Ujike H, Akiyama K, Otsuki S (1990) D-2 but not D-1 dopamine agonists produce augmented behavioral response in rats after subchronic treatment with methamphetamine or cocaine. Psychopharmacology 102:459-464.

Van Oers JWAM, Hinson JP, Binnekade R, Tilders FJH (1992) Physiological role of corticotropin-releasing factor in the control of adrenocorticotropin-mediated corticosterone release from the rat adrenal gland. Endocrinology 130:282-288.

Vanderschuren LJMJ, Tjon GHK, Nestby P, Mulder AH, Schoffelmeer ANM, De Vries TJ (1997) Morphine-induced long term sensitization to the locomotor effects of morphine and amphetamine depends on the temporal pattern of the pretreatment regimen. Psychopharmacology 131:115-122.

Vanderschuren LJMJ, Schoffelmeer ANM, Mulder AH, De Vries TJ (1999a) Dopaminergic mechanisms mediating the long-term expression of locomotor sensitization following pre-exposure to morphine or amphetamine. Psychopharmacology 143:244-253.

Vanderschuren LJMJ, Schoffelmeer ANM, Mulder AH, De Vries TJ (1999b) Lack of cross-sensitization of the locomotor effects of morphine in amphetamine-treated rats. Neuropsychopharmacology 21:550-559.

Vezina P, Blanc G, Glowinski J, Tassin JP (1991) Opposed behavioural outputs of increased dopamine transmission in prefrontocortical and subcortical areas: a role for the cortical D-1 dopamine receptor. Eur J Neurosci 3:1001-1007.

White FJ, Hu X-T, Henry DJ, Zhang X-F (1995) Neurophysiological alterations in the mesocorticolimbic dopamine system with repeated cocaine administration. In: The neurobiology of cocaine (Hammer Jr RP, ed), pp 99-119. Boca Raton, FL: CRC.

Wolf ME (1998) The role of excitatory amino acids in behavioral sensitization to psychomotor stimulants. Prog Neurobiol 54:679-720.

Wolf ME, White FJ, Nassar R, Brooderson RJ, Khansa MR (1993) Differential development of autoreceptor subsensitivity and enhanced dopamine release during amphetamine sensitization. J Pharmacol Exp Ther 264:249-255. 